\title{
Egungo euskarazko literaturaren soziologia kultural baterantz: ispiluak eta tresnak sistema literario eta marko ideologikoen artean
}

\author{
Towards a cultural sociology of contemporary Basque \\ literature: mirrors and tools, betwen system and ideological \\ frames \\ Manu Ahedo Santisteban • mahe@soc.ku.dk \\ KOPENHAGEKO UNIBERTSITATEA, SOZIOLOGIA SAILA, DANIMARKA
}

Recibido: $26 / 12 / 2017$

Aceptado: 16/01/2018

\section{Laburpena}

Artikulu honek literaturaren soziologiaren teorizazioko aurre-estudio bat aurkezten du, ikertze-lanetan erabil daitekeen proposamen teoriko eta analitikoa. Ferguson, Desan eta Griswold-ek (1988) proposatu zuten moduan, literaturaren soziologiak hiru dimentsio analizatzen ditu: testua (ispilua), sistema (demonioak) eta marko ideologikoak. English-ek (2010), literaturaren soziologiaren ikuspegi berrien artean, soziologia pragmatikoa nabarmendu zuen (Dromi eta Illouz, 2010). Berriki proposatutako kultur soziologia konparatu berrituan (Lamont eta Thévenot, 2000) kultur produkzioaren landa/sistema aztertu eta ebaluatzeko proposamen konstruktibista eta erreflexiboa garatu da (Beljean, et al, 2016). Kultur soziologia konparatu zabal honen arabera, gizarteek eta gizarteko aktoreek, beren errealitatea ulertzeko, beren gizarteetan eraikitako tresna ezberdinak erabiltzen dituzte. Literatura da horietako tresna bat, batik-bat errealitatearen ezaugarri garrantzizkoei heltzen dien literatura, eta gutxieneko estatusa eta publiko-irakurlegoa lortutako literatura-lanak. Beraz, literaturaren kultur soziologia bat analisia egiteko ispilua eta tresna metaforak erabiltzeaz gain, sistema literarioa eta marko ideologiko nagusiak analizatzen dira. Analisia egungo euskarazko literaturari aplikatzeko, euskal errealitatearen kontzeptualizazio bat behar da. Euskal errealitate konplexuaren ezaugarri-erronka garrantzitsu bi identifikatu dira: tradizioa-herri eta berrikuntza-hiria munduen arteko zubigintza, eta ezberdinen arteko aniztasuna. Idazle hautagarri askoren artean, garai ezberdinetako hiru idazle ezagun hautatu dira: G. Aresti, B. Atxaga eta K. Uribe. Geroko ikertze-lanetarako galdera eta gai zehatzagoak garatzeko, idazle hauen lanik esanguratsuenek identifikatutako bi ezaugarri-erronkak nola landu dituzten analizatu da.

Hitz-gakoak: konstruktibismoa, kultura, kultura sistema, soziologia kultural konparatua.

\section{Abstract}

This article presents a theorizing pre-study of sociology of literature that can be used as theoretical and analytical frame for research purposes. Ferguson, Desan and Griswold (1988) indicated the three main assets for a sociology of literature: text (mirror), system (demons) and ideological frames. A pragmatic sociology of literature (Dromi and Illouz, 2010) was one of the new perspectives of sociology of literature identified by English (2010). In the recently proposed comparative cultural sociology (Lamont and Thévenot, 2000), a constructivist and reflexive proposal is developed to analyze and evaluate the field of cultural production (Beljean, et al, 2016). Within this broad comparative cultural sociology, societies and social actors, to understand their own realities, are depicted as deploying different tools produced in their respective societies. Literature is one of these tools, especially, those literary works dealing with society's relevant features and concerns, and those that have gained a minimum of status and public. Thus, for a cultural sociology approach to literature the integration and deployment of the metaphors of mirror and tool is proposed, together with the concepts of liter- 
ary system and ideological frames. To apply this analytical framework to contemporary literature in Basque, a conceptualization of Basque reality is needed. In the complex Basque reality two features-challenges are selected: integrative bridging between tradition-village and innovation-city, and pluralism among different. Among the broad population of selectable authors, three writers from different periods and with a considerable status and readership have been selected: G. Aresti, B. Atxaga eta K. Uribe. In order to advance issues for further research, it is thus analyzed how the main literary works of these authors deal with the two identified significant features-challenges of the Basque reality.

Key words: constructivism, culture, cultural system, comparative cultural sociology.

\section{ATARIKOAK ${ }^{1}$}

Egungo gizarte garaikideetan literatura kultur fenomeno inportante bihurtu da. Orohar, gutxieneko irakurlegoa duen literatura bat hizkuntza komunitate horretako gizartearen bere auto-definiziorako iturri eta erreferentzia garrantzizkoa da. Idazle eta lanen kanonizazio prozesuaren ondoren, literatura hezkuntza sistemako kurrikulumetan sartu ohi da. Literatura gizarte garatu baten kultur eta pentsatze-interpretazio sistemako elementua da gainerako elementuekin batera: beste kultur adierazpideak, hedabideak, informazioa eta ezagutza.

Literaturaren soziologian oinarrizko ideia bat egon da (Ferguson, et al., 1988; Griswold, 1993): literatura eta gizartea isla edo ispilu gisako erlazioa dute. Batetik, literatura gizartearen produktua eta isla da. Bestetik, alderantzizko ideia: literatura errefraktatzen duen ispilua da; hots, errealitate sozialaren ezaugarriak islatzen dituen ispilua ere izan daiteke, ispilu horrek gizarteari erreflexioak itzultzen dizkio, eta hauek gizarteak erabiltzen ditu gogoetak, sentimenduak eta sinesmenak eraikitzeko. Beste hitzetan, errealitate kolektiboa definitzeko tresna gisa uler daiteke. Argudio hau pentsamendu pragmatikoan eta konstruktibistan batik-bat izan da proposatua (Rorty, 1989; English, 2010), eta pragmatismoan eta konstruktibismoan inspiratutako kultur soziologia konparatuaren ikuspegian ere bai (Lamont eta Thévenet, 2000; ). Literatura ispilu-tresna gisa analizatzeko, gizarte modernoa eta garaikidea argi ulertu eta definituak behar dira izan.

Ikuspegi teoriko hau euskarazko literaturari aplikatzeko honelako galderak egin daitezke: Zein funtzio du euskarazko literaturak euskal komunitateak bere errealitateaz gogoeta egiteko, eta euskal nazioa, herria edo gizartea definitzeko? Nola islatzen ditu euskarazko literaturak euskal errealitatearen ezaugarri nagusiak? Nola erabiltzen du euskal gizarteak euskarazko literatura tresna bezala bere errealitate konplexua eta anitza ulertzeko?

Aurre-estudio bat teorizazio-prozesuaren lehen urrats garrantzizkoetako bat da (Swedberg, 2012). Artikulu hau honelaxe dago egituratua. Bigarren atalean, egungo literaturaren analisi soziologikoa garatzeko proposamen teoriko eta analitiko bat eskaintzen da: halako makro-soziologia kultural batetik, literaturaren eragina gizartean analizatzeko is-

\footnotetext{
1 Aurreko bertsioa irakurri eta iruzkin eta iradokizun aberasgarriak egin dituzten bi ebaluatzaileentzat eta aldizkariaren editorearentzat nire eskerrik beroenak.
} 
pilu-tresna kontzeptua garatuko da, eta analisi hori egiteko baldintzak eta metodologiaren mugak aurkeztuko dira. Proposamen analitiko hau euskarazko literatura garaikidera egokitu eta aplikatuko da. Horretarako, euskal errealitate anitz eta konplexuan bi ezaugarri identifikatu dira: herri-tradizio eta hiri-berrikuntzaren arteko uztartze-zubigintza eta ezberdinen arteko aniztasuna. Hirugarren atalean marko ideologiko-kultural nagusiak deskribatuko dira. Laugarren atalean euskal sistema literarioaren zantzu eta bilakaera ikusiko da. Bosgarren atalean hiru euskarazko idazle eta beren lan batzuk analizatzen dira: G. Aresti, B. Atxaga eta K. Uribe. Garai ezberdinetako hiru idazleek identifikatutako bi ezaugarriak nola landu dituzten analizatzen da. Seigarren atalean aurre-estudioaren ideia nagusiak aurkezten dira.

\section{LITERATURAREN SOZIOLOGIA KULTURAL BAT}

Gizarte zientziak instituzionalizatu baino lehen, literatura mota bat gizarte zientzia egiteko modu bat izan zen (Lepenies, 1988). Hala ere, literaturaren analisia giza zientzien jarduera izan da gehien bat, eta bertan hainbat ikuspegi garatu dira: ikuspegi linguistiko estrukturalista eta post-estrukturalista, hermeneutika, idazlearen eta irakurlearen gaineko analisiak, etab. Azken hamarraldietan literatura-ikasketak eta kultur-ikasketak garatzeaz gain, bestelako ikuspegiak sortu edota indartu dira, besteak beste, psikoanalisia eta mitoen analisia; analisi kritikoak, adibidez, marxismoak sustatutako ideologiaren gaineko kritika, post-kolonial ikasketa kritikoak, eta feminismoak eta ekologismoak gidatutako analisiak. Hemen, diziplinartekotasunaren onurari muzin egin gabe, literaturaren soziologia bat garatuko da.

\subsection{Literaturaren soziologia: bilakaera eta gaur}

Literaturaren soziologiaren bilakaeran hurbilpen ezberdinak eman dira. xx mendearen hasieran eta erdialdean ikuspegi kritikoak (tradizio marxista, Lukács (1966), Frankfurteko Eskola, adb.) eta funtzionalistak (Coser eta Coser, 1963, adb.) nagusitu ziren. Albrechtek (1954) hiru analisi nagusi diskutitu zituen: literatura gizartearen isla edo ispilu bezala (literaturak gizartearen arauak eta baloreak, kulturaren etika, gizarte klaseen gatazkak eta gizarte egitate-egiak islatzen ditu), literaturaren eragina gizartean (islaren alderantzizkoa, gizarte eta ideien dinamikekin batera), eta kontrol soziala (islaren ikuspegiaren barruko dimentsio bat da, baina gizarte dinamikoetan efektu mugatuekin). Ferguson, et al.ek (1988) ispilua ezezik beste metafora batzuk ere proposatu zituzten: marko instituzionalak eta ideologikoak, eta demonioak edo sistemak. Griswold-ek (1993) literaturaren soziologian errotutako ildoetan (kulturaren ekoizpena, jasotzearen estetikak, kultur kapitala) oinarri hartu eta sortutako ildo berriak bildu zituen: irakurleen esanahien eraikuntza, literatura sistemako sareak eta sare harremanak, literatura ete talde identitateak, irakurle eta erakundeen erantzunen arteko erlazioak, idazlearen autoretza, eta literatura eta gainerako hedabideen arteko erlazioak. Romero eta Santuro-k (2007) bi bide analitiko proposatu zuten: barnekoa (edukia, testuak, etab.) eta kanpokoa (literaturaren ekoizpenaren 
gainekoa). Englishek (2010) literatura analizatzeari soziologiak emandako inspirazio ezberdinak adierazi zituen. Laburrean, ikuspegi asko literaturaren soziologian.

Gai garrantzizko bat da kanon literarioena, hau da, gutxieneko balore estetiko eta unibertsala aitortzen zaizkien lan eredugarriak hautatu eta adostea. Kanonizazio prozesua formal eta informala da eta bi alderdi bereizi daitezke. Batetik, kanonizazioan estatu-nazio bateko ideologia hegemonikoak eta botere politiko-kulturak zeresan handia eduki ohi du. Bestetik, demokrazia garatu eta gizarte ondo hezitu batean partehartze handiagoa egon daiteke, eta bestelako lanak eredugarri eta miresgarri bihur litezke. Kanon literarioen sortze eta irautea analizatzeko gizarte baten botere-sistema eta maila kulturala faktore garrantzizkoak dira.

Zein ekarpen berri egin lezake soziologiak gauko gizartean literatura analizatzeari? Ferguson, et al.ek (1988), H. C. Andersen idazlearen Elurretako Erregina ipuinaren ispiluari gertatzen zaiona hizpide, literaturaren soziologiaren oinarrizko hiru alderdiak zehaztu zituzten:

"The mirror of "The Snow Queen” also boasts an ornate frame and three demons to carry it about the world. That frame and those demons too belong within the purview of the sociology of literature. Critics who focus on the reflections or misreflections of literature usually neglect the frame, that is, the institutional and intellectual context of reflection. Such critics are even less likely to consider the demons, that is, the agents of diffusion and canonization. In sum, the sociology of literature makes a point of what others overlook. It concentrates upon those who hold the mirror. Many studies explore the literary text or literary institutions or writers. A sociology of literature requires the integration of text, institution, and individuals - mirror, frame, and demons.» (p. 429)

Beste hitzetan, literaturaren soziologia baten oinarrizko hiru dimentsioak: a) testua eta lan literarioa; b) marko instituzional intelektual-kulturalak; eta d) sistema literarioa eta hau maneiatzen duten aktore gakoak.

Bestalde, Lamont eta Thévenetek (2000) azken teoria konstruktibistetan bi tradizio uztartze dituzte: Frantziako soziologia pragmatikoa (Bourdieu-ren soziologia, bera ere barne, gainditzeko proposamena) eta kultur soziologia konparatu berritua. Ikuspegi konparatibo honen arabera, estatu-nazio bakoitzak tresneria zehatzak luzatzen dizkie bere kideei bide instituzional batzuen bitartez, komunitate nazionaletako kideek beren errealitatea ulertu eta ebaluatzeko. Bestela esanda, ikuspegi honek gizarteek nola pentsatzen duten konparatzeko proposamena egiten du, pentsatzeko (ebaluatu, baloratu, etab.) gizarteetan indarrean diren marko ideologiko-kulturalak, egitura sozialak eta tresna ezberdinak analizatuz.

Teorizazio hau euskarazko literaturari aplikatzeko honako analisi bikoitza egin nahi da: a) goiko hiru elementuak analisi integratu batean, eta b) ispiluaren metafora zaharra tresna metaforarekin uztartu, horrelaxe objektua den testu literarioari begiratze berri bat eginez. 


\subsection{Marko eta botere ideologiko-kulturalak}

Literatura gizartearen isla dela dion argudioak marko instituzional eta ideologiko orokorrari begiratzen dio. Literaturan gizartearen eragina mota askotakoa da, baina ideologiakultura nagusia edo hegemonikoa nabarmendu ohi da bereziki. Gizarte baten sinesmen kultural eta politikoen artean hierarkiak eta ideologia dominantea daude. Ideologia nagusi hori botere-iturri garrantzikoa da. Hainbat autorek adierazi dute ideologia-botere binomioa, besteak beste, Foucault (ezagutza-boterea), Althusser (estatua-ideologia), Gramsci (ideologia hegemonikoa). Ikuspegi hau kritika ideologikoa edo kultur-ikasketa kritikoak deitu ohi da (Parker, 2008), eta ideologiak errealitatea nolabait normalizatu edo naturalizatzen duela bat etortzen dira. Ekoizpen literarioa ideologia-boterearen eragina eta erabilera aztertu ohi da, lan literarioen kanonizazio prozesuetan ideologiak eta botereak ezkutuan eta zeharka egin ohi dituen estrategiak problematizatuz.

Era beretsuan, literatura lanek, indarrean dagoen literatura eta kultura sistemaren barruan, gizarteko egitura eta beronen mota askotako ezberdintasunak, hierarkiak eta ideologia nagusiak bir-produzitzen laguntzen dute. Tradizio honetan, Bourdieuk (1992) literatura eta gizarte egituraren arteko erlazioak aztertu zituen landa (champ) kontzeptuarekin; zehazki, literatura landaren bipolarizazioa, eta goi-literaturaren kanona gizarte taldeen kultur kapitalarekiko erlazioak egitura sozio-sinbolikoak aipatuz, eta literaturak bere eduki eta funtzionamenduarekin gizarte klaseen arteko ezberdintasunak bir-produzitzen dituela ondorioztatuz. Bourdieuk literaturak gizarte egiturako boterearekin duen heteronomia erlazioaren garrantzia adierazi zuen, literaturak duen autonomiaren ideala ahulduz. Bertan aktore banako eta kolektiboek boterearen alderdi ezberdinen (ekonomikoa, sinbolikoa, politikoa, etab.) iturri diren erakundeekiko erlazioak dituzte. Literatur sistema edo landa boterearen gizarte egiturari dago lotua. Literatur sistema edo landan literaturaren teoria akademiko eta ebaluazio nagusien eragina kontuan hartuz analisi erreflexiboagoa bihur daiteke. Soziologiak boterea eta ezagutza ulertzeko bestelako hurbilpen osagarriak ere garatu ditu. Ez dago hemen gai horretarako espaziorik, eta 2.4. atalean ideia batzuk eskainiko dira.

\subsection{Sistema literarioa: sistema kulturala eta hizkuntz-nazioak}

1970 eta 1980ko hamarraldietatik, Even-Zohar (2005) eta beste autore batzuek sistema literario garaikidea kontzeptualizatu zuten, eta beronen hainbat elementu, aktore, arau edo lege, eta erlazio aipatu zituzten. Aktoreen zerrenda luzea da: idazleak, editoreak, argitaletxeak, sari sistema, itzultzaileak, banatzaileak, literaturaren eta kulturaren hedabideak, kritikoak eta ikerlariak, irakaskuntza, etab. Aktore guzti horien artean hizkuntza batean edo hizkuntza batzuetan (gizarte elebidun edo eleanitzetan) sortu eta argiratzen den literatura antolatzen da. Lehen adierazi bezala, kontu garrantzizkoa dira kanonak, jerarkiak eta sailkapenak. Literatura-lanak, batez ere narrazio eta poesia, sailkatzea eta zerrendatzea oso prozesu gakoa da. Hautatze eta ebaluatze prozesu baten ondorioz idazle eta beren lanen gaineko kategoriak eta kalitatezko zerrendak sortzen dira. Best-seller eta long- 
seller fenomeno adierazgarriak dira. Literatura sisteman botere erlazioak daude, goian ikusi bezala. Hala ere, literatura garaikidea gizarte osoari zuzendutakoa denez gero, sistemaz gain pentsa liteke gizarteak ere badu literatura ebaluatu eta antolatzeko hitzik; sorpresa literarioak (bai argitaletxeak bai idazleak) deitu ohi diren horiek batzuetan erakusten duten bezala.

Europan eta mendebaldean sistema literarioa nazionalak izan dira gehien-bat, hizkuntzesparru bati mugatuta. Literatura nazionala kontzeptuak literatura nazio-estatuen sorreran, produkzioan eta birprodukzioan izandako rola analizatzeko ere erabili da (Even-Zohar, 1993; Romero, 2008). Literatur sistema nazionalen ikuspegia nagusia izan da Europa eta mendebaldeko tradizio akademikoan, eta arazoak ditu estatu/nazio/hizkuntza trinomioa ematen ez den hainbat kasutan, Espainian eta Euskal Herrian kasu, zein bere ezaugarriekin.

Analisi konparatiboa inspirazio ona ohi da. Kritikari dagokionez, Griswoldek (1987) hiru herrialdeetan lan literario berberaren harrera eta iruzkin ezberdinak aurkitu zituen; eta era berean, testuen anbiguetateak eta anbibalentziak efektu ona eta malgua zuela interpretazio ezberdinetan. Gizarte garaikide eta plural batean, iruzkinen artean diferentziak, aniztasuna eta debatea espero izatekoak dira, eta sistema literarioaren osasunaren seinale teorikotzat har daiteke. Argitaletxeei dagokienez, Weber-ek (2000) AEB eta Frantziako argitaletxeetako profesionalen ebaluatzeko tresnak eta errepertorioak erkatu eta bi kasu oso diferenteak aurkitu zituen, lehena horizontalagoa eta botere kontrol gutxiagorekin, eta bigarrena bertikalagoa eta botere kontrol gehiagorekin.

\subsection{Literatura ispilu eta tresna gisa gaurko gizartean}

Albrechtek (1954) gizartean literaturak izan dezakeen eragina aztertzeko orduko pentsamendu pragmatikoaren ekarpenak komentatu zituen, eta Dewey, Gotshalk, Lundberg, eta antzeko autoreen artea eta gizartearen arteko erlazioaren gaineko argudioak aipatu zituen: "that social relations are today managed on the basis of what poets, play wrights, journalists, preachers and radio commentators assume, on the basis of folklore, literature, and highly limited personal experience, to be principles of human nature and human relations» (p. 436). Amerikako Estatu Batuetan (AEB) 1940 eta 1950ko hamarraldietan proposatutako argudioak dira, baina gaur onarpen handikoa den konstruktibismo sozialaren teoriarekin bat egiten dute.

Rorty-k (1989), filosofia pragmatikoaren barruan, gizakien arteko solidaritatearen gaia jorratuz, literaturaren funtzio eraikitzailea azpimarratu du: «The process of coming to see other human beings as 'one of us' rather as them is a matter of detailed description of what unfamiliar people are like and of redescription of what we ourselves are like. This is a task not for theory but for genres such as ethnography, the journalist's report, the comic book, the docudrama, and especially, the novel» (Rorty, 1989: xvi). Maila unibertsala lortutako narratiba lanek irakurleei ikasbide garrantzizkoa eskaini diezaiekete. Adibidez, jende 
baztertuaren sufrimendua eta gizakiok eragin dezakegun krudeltasuna sentiarazi duten narratibak aipatzen ditu: Nabokov-en Lolita eta Orwell-en Animal Farm eta 1948. Rortyk ideia hau gizarte garaikideko kultura sistemara hedatzen du: «...the novel, the movie, and the TV program have, gradually but steadly, replaced the sermon and the treatise as the principal vehicles of moral changes and progress.» (Rorty, 1989: xvi). Konstruktibismo zabal batean Rortyren kontzeptualizazioa hemen proposatzen den ispilu-tresna metaforekin bat dator.

Kulturaren edo kultur soziologian, Swidler-ek (1986) kultura ekintza gidatzen duen tresneria (tool-kit) edo errepertorio bezala ikusteko proposatu zuen. Silber-rek (2003) kultura errepertorio gisako teoria garatu zuen soziologia pragmatikoarekin uztartuz, gizarteek eta aktore sozialek beren errealitateak ulertzeko kultura nola erabiltzen duten analizatzeko. Dromi eta Illouz-ek (2010) hurbilpen hau erabili zuten literaturaren bidez aktore sozialek garatzen dituzten etika balioak aztertzeko: «The new pragmatic sociology does not try to sort everyday moral controversies by bringing the force of critique to bear on the actors' various "ideological" statements and "faulty" rationales...the task of ordering and defining the social should be left to the actors themselves, not taken up by the analyst» (pp. 355). Beraz, gaurko gizartean lan literarioa analizatzeko tresna eta ispilua metaforak egokitzat jo daitezke.

Hurbilpen honek batzuentzat funtzionalismo berritu baten diskurtso analitikoa irudi dezake, baina konparazio, interpretazio eta gizarte aktoreen ekintza eta interpretatzeko aukeretan fokatuz, berritzailea ere badela argudia daiteke. Errealitate soziala bikoitza dela uste da: egitura soziala eta beronen gaineko interpretazio nagusia uztartuak. Teoria hau gida harturik, ezagutza, kultura eta literaturaren gaineko analisia oso garrantzizkoa da.

\subsection{Edukiak: literatura eta gizartearen ezaugarri hautatu batzuk}

Literatura ispilu-tresna gisa analizatzeko, gizarte moderno eta garaikidearen oinarrizko ezaugarri gako batzuk hautatu behar dira. Gizarte modernoaren sorreran teoria sozial klasikoak aldaketa estruktural bat idealizatu zuen: tradizio-komunitatetik berrikuntzaelkartezko gizarterako trantsizioa, nekazal-inguru batetik hiriko kontestu baterako, edo laburbilduz, herritik-hirirako aldaketa. Teoria sozialak aldaketa hau gizarte tradizionaletik gizarte modernorako trantsizio gakoa bezala ulertu baina gehiegi mitifikatu zuen. Trantsizioa ez da inoiz erabatekoa izan, eta bi munduak batera eta elkarren pare geratu dira, beren kontraesan eta osagarriekin. Barnes-ek (1995) «myth and reason» kodan argiro erakusten ditu teoria sozialaren idealismo honen ahulezia eta efektuak. Beraz, gizarte modernoaren erronka bat tradizio-mitoa eta berrikuntza-arrazoimena bereiztu ordez uztartzea, eta komuneko zantzuak aurkitzea da. Bestalde, gaurko gizarte garaikidearen gaineko soziologia enpirikoak bi ezaugarri nabarmendu ditu: mota askotariko pluralitatea eta gizarte erlazioen eta sistemen konplexitatea. Gizarte garaikide gehienek, nahiz eta Europan sortutako nazio-estatu eredu homogeneizatzailean antolatuak egon, mota askotako plu- 
ralitatea dute maila eta eduki ezberdinetan. Gizarte hauen ezaugarrietako bat oinarrizko pluralitatea aintzat hartzea da, hots, aniztasuna. Hortaz, egungo gizartearen erronka bi proposa daitezke: oinarrizko justizia eta berdintasun sozialen barruan herri-tradizio-komunitate eta hiri-berrikuntza-gizarte munduen arteko txertatze-zubigintza, eta ezberdinen arteko aniztasuna.

\subsection{Ispiluak eta tresnak aztertzeko baldintzak eta metodologia}

Literaturak gizartean eduki dezakeen ispilu-tresna gisako eraginak baditu baldintza batzuk, eta analizatua izateko metodologikoan zenbait arazo eta erronka ere bai.

Baldintzei dagokienez, hemen bi aipatzen dira. Lehen baldintza literatura errealista izatea da. Gizarte garaikidea konplexua eta anitza da, eta beraz, idazlearen aukera eta ahalmena da erreferentzia bezala hartzen duen gizartearen ahalik eta errealitaterik anitzen eta konplexuena jorratzea, pertsonaia sorta zabalekin eta gizartearen garrantzizkoa gaiak landuz. Idazle batek hein batean soziologiaren antzeko lana egin dezake, hau da, errealitatea deskubritu eta errealitate horretako aniztasuna eta konplexitatea nobeletan eta poemetan islatu. Bigarren baldintza gutxieneko irakurlegoa edo estatusa izatea da. Literatur sistemaren galbahea igarota, gizarte zabalera iristen den lan literarioa izan behar da. Hemen denbora faktorea hartu behar da kontuan, literatura-lan batzuek denbora behar baitute onarpena eta irakurlegoa lortzeko.

Metodologiaren aldetik, badira zenbait erronka. Posible diren datu kuantitatibo eta kualitatibo guztiak lagun, metodo egokiena analisi diakroniko eta kualitatibo bat izan daiteke. Gizartean aldatze-tempo geldoa izan ohi denez, denbora tarte luzea kontutan hartzea beharrezkoa da. Ispilu edo tresna gisako eragin prozesua analizatzeko analisia konplexuagoa behar da. Ikerketaren hurrengo pausua hautatuko obra literarioen gaineko interpretazioa irakurleei galdetzea litzateke, eztabaida-taldeen metodoa egokia izanik. Artikulu honetan, literatura ispilu edo tresna gisa analizatzeko lehen partea bakarrik egiten da, hots, gai jakin batzuen inguruan ispilu eta tresna gisako eragina eduki dezaketen literatura lanak aztertzea.

\section{EGUNGO EUSKARAZKO/EUSKAL LITERATURA: MARKO INSTITUZIONALAK ETA IDEOLOGIKOAK}

Euskarazko literatura aztertzeko marko ideologiko-kultural estrukturalak eta koiunturalak izan behar dira kontuan. Frantziarekin izandako erlazioak bestelako analisi bat behar luke, eta Espainiarekikoa bakarrik aztertuko da. Espainiako marko estruktural eta koiunturalen barruan euskal kulturak eta gizarteak bere dinamika antzeko eta bereiziak izan eta garatu ditu. Espainiaren kasuan, anbizio handiko estatu bati ohikoak gertatzen zaizkion kultura eta ideologia hegemonikoak aipatu behar dira. 
Bi alderdi estruktural bereizi daitezke: historia eta ideologia/diskurtso modernoa. Lehena, Espainiako historia bortxaz, autoritarismo eta elitismo kultural eta politikoz betetako historia da, eta demokraziaren eta gizarte alfabetatu baten eskarmentuak oso laburrak. Kontestu historiko horretan kulturaren produkzioa, ebaluazioa eta erabilera mugatua eta kontrolatua izan da. Nazionalismo kontserbadorearen korrontea oso indartsua izan da, eta Espainiar nazionalismo eta periferietako nazionalismoen artean mota askotako talkak izan dira. Bigarrena, ideologia moderno eta hegemonikoa. Estatu moderno orok garatu ohi du auto-justifikatzeko eta boterea erabiltzeko modernotzat aurkezten den aparatu ideologikoa. Espainiaren kasuan, Europako modernitate liberalago eta dinamikoagoekiko halako frustrazioz osatutako ideologia hegemonikoa garatu da, autoritarismo kontserbadorea zuritu duen diskurtso zentripetuan (Subirats, 1993, adb.).

Korronte koiunturalen artean hiru garai ezberdin bereiz daitezke: a) diktadura frankista eta bereziki bere azken hamarkada edo tardofrankismoa, herri mobilizazioekin eta diktaduraren biziraupen gogoekin; b) demokraziarako trantsizioaren ingurukoa, frustrazio eta espektakulu bihurtu zen ilusioa (Vilarós, 1998; Subirats, 2002); eta d) azken hamarkadetan globalizazioa, bere zantzu neoliberalak eta indibidualistak, kultura eta literaturaren munduan halako "post» ikuskera ezberdinak (post-modernoa, etab.) hedatuz; globalizazioaren anbibalentziaren barruan zera argudia liteke: korronte politiko-ideologikoen aldetik konbergentzia formal handiagoa gertatu da, eta eremu kulturalean halako eduki-pluralitate handiagoa suertatu da.

Euskarazko literaturaren historia gehiena, salbuespenez aparte, nolabait Espainiarekin batera izandako korronte kontserbadore eta katolikoan murgildu da. Benetako aldaketa 1960ko hamarkadan gertatzen hasi zela adostasuna dago (Aldekoa, 2008; Kortazar eta Retolaza, 2007). Hamarraldi horretan nobela modernoa sortu zen Txillardegi eta Saizarbitoria bezalako idazleen eskutik, aurreko nobelagintza nagusia ohiturazko eta kontserbadore samarra baitzen. Arestik poesiari ekarpen berria egin zion, poesia orduan zantzu erromantikoen pean baitzegoen. Euskalkien arteko euskara batua adostu eta estandarizazioa hasi zen. Harrez gero, euskarazko literaturan joera eta tradizio dezente garatu dira, aurrera-atzerako mugimenduekin eta konbinaketa ezberdinekin.

Edukiez ari garela, Aldekoak (2008) denborarekin bizi eta anitza bihurtzen den bilakaera aurkitu zuen. Kortazar eta Retolaza (2007), Retolaza (2007) eta Kortazar (2009) analistek azken hamarraldietako eleberriaren eta poesiaren bilakaera aztertu dute, eta lan esanguratsuak hautatu eta analizatzeaz gain, bi genero hauek izan duten bizitasuna azpimarratu dute, are euskarazko literaturaren tamaina txikia kontuan hartuta. Gabilondo-ren ustez (2016), euskal, iberiar eta latino-amerikar ikasketa kritikoen barruan "subalternist-postnational-differential approach» batetik euskal/euskarazko literaturaren historiak zantzu periferikoak izan ditu bi nazio-estatu handien nazionalismoen erdian. Zaldua (2016) idazlea eta kritikoak azken hamarraldietako edukiari eta proposamen literarioei begiratuta, aniztasuna, berrikuntzarako ahalmena eta nolabaiteko benetakotasuna azpimarratu du. 
Euskarazko literatura eta ideologien arteko erlazioa ikuspegi ezberdinetatik izan da aztertua. Batetik, Gabilondo (2016), Atutxa (2014) eta beste autore batzuen ustez, literaturan ideologiaren presentzia ia nahitaezkoa izanik, euskarazko literaturak botere-ideologia indartsuen eragina jaso du marko ideologiko eta politiko hegemonikoen barruan. Bestetik, Kortazar (2016), Sarasola (2016), etab., literaturaren eduki estetikoa des-ideologizatzearen garrantziaz eta aukeraz aritu dira. Gai hauen inguruko debatea seinale ona da, eta literaturari onurak ekarriko bide dizkio. Ideologia aztertu beharreko fenomeno sozial garrantzizkoa da. Literatura sortzeko autonomia goi-kulturaren helburu ideala da. Soziologia enpiriko batentzat, ideologiak eta idealak literaturaren prozesu osoan aurki daitezke: sortze-jardueran, ekoizpenean, eskaintzan, irakurlegoaren harreran eta baita interpretazioan ere; kasu batzuetan laguntza, beste kasu batzuetan oztopo; batzuetan ageritan, beste batzuetan ezkutuan. Hemen, ideologien eraginez gaindi, euskarazko literaturaren gaineko bestelako analisia egin nahi da.

\section{EUSKARAZKO/EUSKAL LITERATURAREN SISTEMA}

Sistema literarioak hizkuntzetan oinarritu ohi dira, eta euskal errealitate eleanitzean euskararen normalizazioa kontu gakoa da. Euskarazko alfabetatze-prozesua berandu samar hasi zen. Frantzian egoera bestelakoa izan delarik, Espainiar estatuaren barruan 196070ko hamarraldietan euskara batua adostu ondoren, geroko hezkuntza eta hizkuntza politikek euskal gizartearen euskarazko alfabetatzea abian jarri zuten, batez ere belaunaldi berrien kasuan. Zenbakiek aurrera egin ahala (astiroegi batzuentzat, espero zitekeen abiaduran beste batzuentzat), euskarazko literaturak potentzialki gero eta irakurlego handiagoa izan du. Euskarazko literaturaren lehen publikoa euskaradunak dira, eta bigarren publikoa itzulpenen bidezkoa, bereziki gazteleradunak euskal gizartean.

Espainiaren sistema literarioa bertikal samarra da, batez ere kanonizazio prozesuei dagokienez. Francoren diktaduraren garaian ezarritako sari-sistema gakoa da kanonizazioprozesuak ulertzeko. Bi sari mota nagusi dira: gobernuenak (genero nagusien sari nazionalak eta iruzkingileen elkarteak erabakitako kritika saria; eredu hau autonomi erkidego askotan ere hedatu da) eta argitaletxeenak (kantitate ekonomiko esanguratsuekin). Sarisistema hierarkiko eta bertikal honen bidez, estatuarekiko botere politikoak eta sistemako enpresarik handienek beren interesak defentsa ditzakete. Oso gutxi dira, ordea, irakurleen sariak edo herri-liburutegien bidez antolatzen diren sailkapenak eta zerrendak. Eta iruzkinek gehiegitan hedabide eta argitaletxe enpresa handiekiko nahiko lerrotuak ematen dute.

Euskarazko sistema literarioari dagokionez, oztopoak (diglosia linguistikoa eta apur bat literarioa ere bai), kritikak (diru-laguntza eta politika ez-egokiak) eta autokritikak (hurbil eta urruneko beste hizkuntzekiko eta literatura sistemekiko erlazioak) gorabehera, azken hamarkadetan nolabaiteko literatura sistema homologatu eta garatua eraiki dela esan liteke (Olaziregi, 2009). Bere hasiera 1980ko hamarraldian koka daiteke. Garai horretan 
produkzioa eta argitaletxeak hazi ziren, sari ofizialak ezarri ziren, itzulpenak igo ziren, eta euskarazko literatura gizartearen eta baita hezkuntza sisteman elementu presenteago bihurtu zen. Politiko eta ideologikoki garai bizia eta sutsua zen, baina kultur eta literatura arloan halako sormen kritiko anitza eta ahalegin kolektiboa nolabait batera zebiltzan. Ezari-ezarian idazleen artean literatura-kanon informalak edo erdigune-periferiak sortu dira, faktore kualitatibo eta kuantitatiboen eraginez (Alonso, 2012).

Sistema literarioaren gaurko osasunaz, askotariko iritziak daude. Batetik, Egaña-k (2015) literatura-lanen kritikaren gehiegizko positibotasuna azaleratu du: 1975etik 2005erako epealdian Euskal Herrian egindako 2.300 kritika iruzkinak aztertuz, \%84 positiboa edo oso positiboa dela aurkitu du. Egañak eboluzio bat ere identifikatu du: 1980ko hamarkadan kritika eta eztabaida anitzagoa zegoen eta 1990ko hamarkadatik aurrera, berriz, kritikak gero eta aldekoagoak ziren. Egañaren ustez, halako homologazio baten proiektua zegoela antzeman daiteke, agian kanpoan eta batez ere Espainiako kultur produkzioaren legitimazio erakundeetatik onarpena lortu nahian. Kulturan eta literaturan estatus eta onarpen sistemak hierarkiak ere izan ohi ditu. Espainiako sariek euskarazko literaturan izandako gehiegizko eragina sarritan izan da kritikatua. Bestetik, Zalduak (2016) euskarazko literaturaren azken eboluzioan askotariko dinamikak aurkitu ditu, oro har literatura homologatu baten ezaugarri gehiago erakutsiz. Egia esan, ekimen horizontalago zenbait sortu dira. Adibidez, Akademia 111 delako ekimena: bere plataforma digitalean izena emandako irakurleek iruzkinak egin ditzakete (2018ko apirilean webguneak 200 irakurle direla dio), eta 1996tik urtero eleberri onena hautatzeko bozka dezakete. Tokian-tokiko irakurleklubak ere hedatu dira. Teknologia digitalak direla medio, literaturaz eztabaidatzeko, zenbait sare interesgarri sortu dira, adibidez: www.armiarma.eus. Sistema ebaluatzeko atrebentziaz, zera iradoki daiteke: zenbat eta sari instituzional gutxiago (batez ere ofizialak eta argitaletxeenak) eta ekimen horizontal gehiago, literatura eta sistema garatu eta hobetzeko orduan eta aukera gehiago egon daitezke.

\section{EGUNGO EUSKARAZKO LITERATURA ETA EUSKAL ERREALITATEAREKIKO ISPILUAK ETA TRESNAK: ARESTI, ATXAGA ETA URIBE}

Azken hamarraldietan gizonezko idazle batzuk goraipatuak eta hierarkiaren goiko postuetan agertu dira (Alonso, 2012): G. Aresti, B. Atxaga, R. Saizarbitoria, J. Sarrionandia, A. Lertxundi, etab. Alonsok bigarren mailako irakaskuntza sisteman 2004-06 urteetan aurkitutako dozena bat inguruko idazle-erdigunean emakume bat bakarrik egotea deigarria da. Gaur egun balizko zerrenda horretan U. Elorriaga, H. Cano, K. Uribe eta beste idazle zenbait, batzuk ere emakumezkoak, egon litezke. Idazle hauen goi-posizioa ulertzeko arrazoi desberdinak izan daitezke: literatura sistemarekiko faktoreak, ezaugarri pertsonalak (ahalmenak, estiloa), hizkuntzarekiko zailtasun maila apala, etab. Beste arrazoi bat idazle hauek beren lanetan euskal errealitatearen ezaugarri garrantzitsuak landu izana 
izan daiteke. Beste idazle gehiago hauta zitezkeen. R. Saizarbitoriaren kasuan, bere nobelak euskal jendeen gerra zibiletik orain arteko historiaren gaineko gogoeta egiteko aproposak dira. J. Sarrionandiaren kasuan, bere bidaietako poesian Europako eta mundu klasiko hiriak eta tokiak dira erreferentziak. A. Lertxundiren kasuan, bere nobelagintza oparoak hainbat gai landu ditu. Hautatutako hiru idazleak ikerlariek gehien analizatutako idazleen artekoak dira, eta horrek analisia laguntzen du.

\subsection{G. Aresti: hiri-herri arteko zubi kritikoko jende xehearen askatasuna}

1960 eta 1970ko hamarraldiak Frankoren diktaduraren azken urteak izan ziren, mundu itxia eta garai iluna. Diktadurari aurka egiteko politika-mobilizazio posibleez kulturan haize berriak eta aire zahar berrituak ibili ziren. Hiriak gero eta handiagoak ziren industrializazioaren kolpeaz. Hainbat euskal tradiziok baztertuak segitzen zuten, sistema literarioa eta euskara indar kontserbadoreen eskuetan zegoen. Literaturan zentzura politiko zorrotza zegoen.

G. Arestik, Bilbao hirira mugitutako familia baten semea, euskara bere kabuz ikasi ostean, bere literaturan kontraesanez betetako errealitate anitz eta ez-justuari heldu zion. Bere poesia-lanik garrantzizkoenak: Maldan behera (1960), Harri eta herri (1964), Euskal harria (1967), Harrizko herri hau (1971), Azken harria (1979). Kortazarren ustez (2016), Mailu batekin; biola batekin (1961) trantsiziozko lana da. Azken hamarkadetan, Arestiren lan guztiak, poemak, antzezlanak, artikuluak, etab. bildu dituzten edizioak daude, erakunde eta argitaletxe ezberdinek argitaratuak (adb. Aresti, 1984, 1986, 1995). Arestirentzat antzerkia herri xehearentzat literatura generoa egokia zen (Del Olmo, 2016). Bere literatura eta ibilbidea goraipatua zein kritikatua izan dira.

Bere poesia soziala izan zela adostu da, eta beste poeta sozialen eragina aipatu ere bai, Blas de Otero eta Gabriel Celaya, esaterako. Hala ere, ezaugarri sozial horren barnean bestelako ñabardurak ere badira. Aldekoaren iritziz (1993), Arestiren poesiak bidaia bat egin zuen sinbolismo indartsu batetik (Maldan Behera) gero eta poesia sozialago batera, estilo eta lengoaia aldaketa esanguratsuak eginez. Atienza-k (Aresti, 1984), bildumaren sarreran, poetaren profeta-irudia nabarmentzen du, eta bere poesiaren kontraesanak (adibidez, behin eta berriro aipatutako poetaren egiak baina gutxitan zehaztuak; hau agian zentzuragatik uler daiteke) eta ez-orekak ere (adibidez, ni poetikoaren gehiegizko indarra). Kortazarren analisian (2016), Arestiren poesiak ideologizazio prozesu bat izan zuen lau ildotan: poesiarako hizkuntza (euskara), estetika, Eusko Alderdi Jeltzalearen imajinario politikoari kritika, eta kristau fede galduaren agnostizismoa. Arestiren poesia ideologia ezkertiarra eta sormen literarioaren arteko erlazioen adibide bat izan zen.

Arestiren poesia herria eta hiria munduen arteko zubiak eta erlazioak eraikitzeko egokia da. Lehen poema-liburuan, Maldan Behera, Nietzsche filosofoaren ideiak soma daitezke, agian Mirande idazlearen bitartez. Halako goi-zeru-mendi batean sortu eta handik behera, haranerantz edo hiri-bitarte-rantz datorren gizaki berriaren pertsonaia dugu, behe- 
lurreko gizakiak salbatzera etorria, azkenean hasierako mendi-goi-zerura bueltatzeko. Bidaia horretan ildo nagusi batzuk lantzen dira: maitasunezko istorio bat (Miren emakumearekin; Arestiren emakumeen ahotsari ez ziola entzun kritikatu da); gizakiaren eta gizateriaren bilakaera gaurko egoerara arte; eta super-gizakiaren patua: jaitsiera, juzgatua, gurutzatua, berpizkundea, igoera eta mendekua. Erlijioz betetako irudien bidez eta gizakiak natura-animaliekin duen erlazioa erabiliz herri-munduko jendearen bizitza salbatzearen beharra eta ezina adierazten du.

Harri eta Herri liburua poesia sozial baterako trantsizioa da, eta dagoeneko gai sozialen zantzu argiak erakusten ditu aldarte itxaropentsu batekin. Herri xehearen duintasunezko ikuspegitik euskal kulturaren eta euskararen gaineko gogoetak eskaintzen ditu, batez ere bi poema luzeetan: Profeta bati (J. Oteiza eskultoreari azaldu nahirik), eta Astepeko sekretarioaren bertsoen atalak. I. Sarasola analistaren arabera, Harri eta Herri obrak lau ezaugarri nabarmentzen ditu: ${ }^{2}$ gaien berriztea, hiriko paisaia, poesia sozialean murgiltzea eta oso kutsu ez-erlijiosoa edo laikoa. Lau zantzuok elkarrekin modernitatearen ikurra ematen diote poesiari, modernitate kritiko bat ohiko botereekin, eliza katolikoarekin eta kapitalismoarekin. Modernitatearekin batera sortutako herri-jende berri eta xehea bazterretatik atera nahi du, langileak (euskaldunak eta ez-euskaldunak), etorkinak, hiriko eguneroko biztanleak, etab., hots, herri xehea. Arestik, bere burua munduko neurritzat hartuz, inoiz ez esandako egiak esatera etorri dela dio, bere egia eta beste egiak isilarazteko indarrak salatuz. Herriak Arestirentzat bi adiera dituela esan daiteke: antolatutako gizartea bere botere, arau eta errepresioarekin, eta eusko/euskal lurra, atzerriko eskuek eta interes ekonomikoek bahitutako herria. Herria anbibalentziaren adibidea da nazio, komunitate edo gizarte oro bezalaxe. Arestik hiri-herri-ko jende xehearen ahotsa jarri zuen bertsotan. Herri xehearen kontzeptuan mota askotako taldeak dira: nekazariak, arrantzaleak, laborariak, hiriko biztanleak, euskal paisaian zehar dabiltzan hezur-haragizko pertsona arruntak, denak botere sistema baten menpe biziraupenean, onarpenik gabeko ohiturazko kulturetan. Jende xehea aitaren etxea zen, batzuetan euskara, baina oro har herriaren usadio duina. Aitaren etxea defendatuko dut poema ezaguna era ezberdinetara uler daiteke, baina sakonean, oztopo eta sufrimenduen kontra usadio xehearen defentsa irmo eta pazifikoa da, hasieran, iraganeko eta usadiozko elementuak (hazienda, soloak...), gero hiriko elementu modernoak (interesak, errentak,..), eta azkenik gorputzeko zatiak.

Euskal Harria (1967) liburuan Arestik argien lantzen du herri-hiri arteko zubi gezi-gozoa. Zorrozki zentsuratuko liburu honetan, herria zein hiria, biekiko kritiko azaltzen da Aresti, bietan boterearen hatzaparrak eta modernitatearen zapalkuntza salatuz. Aldekoaren ustez: «Euskal Harria-z geroztik... ez dago garbi nor bizi den aitaren etxean eta nor kanpoan. Arestiren poesia haize kontra zihoan: bere kontzientziaren eta sentiberatasun poetikoa orroka ari ziren hiriak eta hiriko jendeak jasaten ari ziren zapalkuntzaren eta bidegabekeriaren kontra, Aresti bera eta bere familia barne» (2002: 247). Arestiri bizkarra emana zioten katoliko-kontserbadoreek, eta orduan nazionalistak ere berdin hasi ziren. Jende xe-

${ }^{2}$ Atienzak aipatzen du berak idatzitako sarreran eta analisian (Aresti, 1984). 
hearen arteko aniztasun eta elkartasunaren beharra indartzen da, kontraesanak eta anbibalentziak areagotuz. Batetik, herriak edo nazioak bere bihotz-burua astintzen dio, usadio eta erronken artean, adb. Bego Euskalerria olerkian:

«Bego euskalerria / zahar eta berria / hala jantzirik txit dotorea / nire soinean kapa morea / garizumako hau kolorea / fina daukat gerria / ez dirudit txerria. Euskalerriko sei-zazpi probintzietako izaerak eta ezaugarri ezberdinak adierazi ondoren, zera idazten du: bego euskalerria / estutasun larria / begi gabiltza duda-mudetan / bihotz-begiak barne-muinetan / ikusi zuten zeru-mugetan / nire eztul urria / eta nire belarria.» (Aresti, 1995: 185)

Bestetik, hiriarekin maite-gorrotozko sentimendua du, Bilbaoko kaleak poeman bezala:

«Bilbaoko kaleak / gora eta behera / errekatik mendira / batzuk artezak / gehienak zeiharrak / lurra estali da / etxez eta gizonez / gizonak leku batetik bestera / eramateko makinez / bizioz eta bekatuz / karitatez eta kriminaz / plaza biribilak / zumari zabalak / zuek niri gogora ekartzen didazue / hire asmo zaharra / behin egin nahi ukan nuen / eta inoiz egin ez dudana / Autonomia / Adiskidetasuna / Libertatea / Foruak / maitatu ditudan gauzak. / Urkijo ministroa / Gardoki kardinalea / Mazarredo almirantea / Egia jenerala / Arrikibar ekonomista / higuindu ditudan gizonak / kaleak, kale hotzak / kaleak hemendik, hortik, handik, edonundik....» (Aresti, 1995: 63)

Bi olerkiotan Arestik herri eta hiri munduekiko gogoeta, kritika eta zubigintza adierazten ditu, biak anbibalentziaz betetako munduak, baina elkarrekin moldatu beharreko munduak, bietako jendarte xehearen arteko aniztasuna eta duintasuna aldarrikatuz.

Laburbilduz, Arestik bere poemetan errealitate kolektibo konplexu, latz, anitz eta kontraesanezkoa islatu zuen, mota ezberdinetako ageriko eta ezkutuko injustiziak salatuz. Garai kontserbadore eta autoritario haietan, Arestik jende xehearen ahotsa altxatu zuen. Bere poemen bidez iradoki egin zuen euskal jendarteak aurrera begira eraiki beharko zuen errealitate berri bat, non herri-usadioak eta hiri-berrikuntzak uztartu beharko ziren komunitate justuago batera abiatuz eta jende xehe ezberdinen arteko elkartasuna sustatuz.

\subsection{B. Atxaga: hiri-herri binomioa eta berrikuntza estetikoa}

1970 eta 1980ko hamarraldiak esanguratsuak izan ziren. Politikaren aldetik, demokraziarako trantsizioa izan zen eta mobilizazio politiko-soziala sutsua egon zen, ETA jarduera hasi eta errotu zen garaia. Literaturaren aldetik, sormen-bide berriak bilatzen ziren. 19752000 epealdi luzea trantsizioko literatura ere dei daiteke (Aldekoa, 2008). Sarasolak (2016) hamarraldi hauetan ideologia eta literaturaren autonomiaren aldeko dinamikak aztertu ditu, batez ere Ustela (1975-1977), Pott (1977-1980) eta Oh! Euzkadi (1980-1983) aldizkarien bidez; B. Atxaga, K. Izagirre eta R. Saizarbitoria-k gidatuta, euskal literaturaren esparrua 
arnasberritzea ezezik, literatura sistema ere bultzatu egin zuten. 1980an sortutako Oh! Euzkadi-n Izagirrek eta Saizarbitoriak «kontsentsu denen aurrean baina-k jartzeko prest» zeudela adierazi zuten. Gabilondoren (1993) ustez, Atxaga, Sarrionaindia, etab.en Pott Banda-ren ekarpenak euskarazko literaturan lehen kanon edo eredu modernoa sorrarazi zuen, Europako korronte sinbolistak, etab., Ziutateaz eta Etiopia bezalako lanetan garatuz.

B. Atxaga euskarazko literatura garaikidearen idazle kanoniko bezala kontsideratu da, arrakasta literarioan oinarritua. Bere lehen bi obra poetikoak edo prosa-poesia hiri modernoarekiko anbibalentziaren adierazgarri dira. Ziutateaz (1976) lanean abanguardia estetiko batean, eroz, suizidioz eta baztertutako jendez osatutako istorioak daude. Etiopia (1978) liburuan, berriz, aberririk gabeko protagonista alderrai dabil planoak desagertu zaizkion hiri batean, non jada poesiarik ez dagoen eta biztanleak harat-honat eta noraezean dabiltzan. Hiria da bi obra horietan erreferentzia nagusia. Aldekoari jarraituz (1993), bi lan horietan Atxaga hiri modernoetan barrena alderrai dabilen poeta edo poeta izan nahi duenaren tokian jartzen da, eta norabide jakinik gabeko bere bizitzan hiriaren beste aldean existitzen ez den ilusiozko utopia baten bila, baina bilaketan goza daitekeen utopia. Obra horietan, Atxagak denbora eta espazio ideiak eta dimentsioak txikitu eta ezereztu egiten ditu. Herdoilarena poema hiriaren izaera anbibalentea adierazle:

Herdoilaren tristeziarekin batera / ziutate honen soinekoa udazkenetan lanbroa da / eta bere sabai laino baso bat / non bizi den ilargiaren badaezpadako agonia. / Eta kalatxorien habi eskaleen sakelak, eta sukalde proletarioaren argi urdinskak / murrail erraldoiaren begi gauero; / zubi zaharretatik / ibaiari so berripaper saltzailea / hitz ezezagunen hiztegi bati bezala; / bus txofer batzu bozeolari hilaz mintzatzzen, / apatridak bailiren trenak / memoria karrilen fatalitatean galduz; / denboraren oihal xinglea arratsezkoa soilik; / arrabita baldarren nostalgia kantoietan, / haruntzago moskorrak, / kale garbitzailearen beilegi bizia, / beste zubi bat, prostitutak. (Aldekoa, 1993: 188)

Olerkiak hiri modernoetako bizitza gezi-gozoa aipatzen du, ezinbestean elkarrekin bizitzera lerrotutako pertsonak bilduz. Olerkigintza abangoardista eta lengoaia ez-zuzen eta ez-argi batean ezinbestez onartu beharreko modernitatearen hiri mundu anbibalentea adierazten du.

Hiri modernoan egindako bidaiaren ostean Atxagak halako herri asmatu batera egiten du ostera Obabakoak (1988) aurreko urteetan idatzitako ipuin eta narrazioen bilduma integratuan. Liburu honegatik Atxagak Espainiako Narratibako Saria lortu zuen 1989a, eta liburua izan da euskaraz idatzitako liburu ezagunena eta itzuliena. Obaba modernitateari ezinbestez begira dagoen nekazal-mundu baten modura uler daiteke. Bertan, naturaren erdian eta ondoan (animaliak, izadia, etab.) hiriarekin zerikusia duten pertsonaia gakoak daude: Alemaniako mundu aurreratu eta komertzialeko Hanburgo hiritiko ingeniaria, eta herrixkara maistra etorritako emakumea, esaterako. Pertsonaia hauek errealitatearen kontraesanak eta babesguneak azaleratzen dituzte. Aldekoak adierazten due- 
nez, Obabakoak sormena eta gogoeta literario elkartzen dituen ibilbide luze baten gailurra da. Meta-literaturaz blai diren ipuinak bi espazio literariotan banatzen dira: «Obaba eta Hanburgo. Lehenengoak iragana iradokitzen du, orainaldiraino iraun duena, oinarrizko pentsamolde batean preso. Bigarrenak, berriz, hiria eta modernotasuna irudikatzen du» (Aldekoa, 2008: 312). Ipuinetan errealitate ezberdinak daude txertatuak, natura, animaliak eta pertsonak, denbora eta urtaroak, idazlea bera eta bere pertsonaiak. Giza errealitatearen aniztasuna elkarrekin eta elkar-uztartua balego bezala, eta bereziki izadiaren naturari lotutako mundua eta hiriko giza naturari lotutako mundua agertzen dira, bi munduak aldi berean hain urrun eta hain hurbil. Eta ez bakarrik euskal espazio kulturalean, mundu zabalean baizik, Hanburgo hirian edo Amazoniako oihanetan ere bai, esaterako. Gabilondo (2016) eta Atutxa (2011; 2013) analisten arabera, Obabakoak euskal nazioaren alegoria egiten zuen liburua zen, euskal errealitateari buruz balizko esentzia kolektibo, exotiko, magiko, subalterno eta ez-moderno baten irudipena zabalduz, eta bestalde obraren arrakasta Espainiar literatura-kultura sistema hegemonikoaren menpe jarriz. Mercero-k (2015) Aldekoa eta Olaziregiren analisia hedatuz, Obabakoak-ek bi mundu-ikuskeren erlazioak lantzen dituela argudiatu du, hain zuzen, mitoa/tradizioa eta kultura/arrazoina, biak nolabait elkarren ondoan eta beharrean. Ezagutzaren soziologia eta teoria enpirikoan arrazoina eta mitoa txanpon bereko bi aldeak bezala dira (Barnes, 1995); beraz, kontua ez da obra, obra interpretatzen duten gizarteko ideologia nagusiak baizik.

Obabakoak liburuak Atxagaren garai bat itxi zuela argudiatu da. 1990ko hamarkadan euskal historian garrantzikoak izan diren gai politikoak jorratu ditu, gerra zibila, ETAren sorrera eta partaideen jarduera, etab. gehienetan pertsona bakanen dilemak, galderak eta gogoetak landuz. 2003an Soinujolearen semea eleberria argiratu zuen (2003ko Akademia 111 Saria), eta Apalategi-k (2009) analizatzen duenez, istorioak hiritiko ihesa bat islatzen du erreferentzia maila batzuetan (euskal, espainiar eta Ipar Ameriketako Kaliforniaren global maila): «Probintziak metropoliaren begirada behar du existitzeko. Hauxe litzateke B. Atxagaren azkeneko obraren konklusio pixka bat etsitua, eta hiritik ihes egite zuhur eta anbiguoaren arrazoina» (Apalategi, 2009, p. 70). Azken urteetan Zazpi etxe Frantzian (2009) eta Nevadako egunak (2013) lanekin halako nazioartekotzeari jarraitzen diola dirudi.

Laburbilduz, B. Atxagak euskal errealitatearen ezaugarriak eta erronkak era sinboliko eta metaforikoen bidez landu ditu, euskal komunitatearen galderak eta dilemak jorratzeko halako errealismo magikoa erabiliz, eta tradiziozko komunitate batek etorkizunari begira beharko zuen berrikuntza estetiko bat proposatuz.

\subsection{Kirmen Uribe: herri-hiri bitartetik errealitateetako etika txikira}

2000 eta 2010ko hamarraldiek korronte berriak izan dituzte. Politikaren aldetik, ETAren ahultzea eta etetea, eta gatazka eta krisi konplexu berriak agertu dira. Oro har, globalizazio neoliberalaren goreneko uneak izan dira, eta berarekin etorritako "post» ezberdinak. Euskarazko literaturan, idazle berriak sortu dira, aniztasuna eta kalitatea handitu egin da, eta literaturaren kritika eta analisi arloak ere sendotu direla dirudi. 
Uribek poema-lan batzuk argitaratu ostean 2001.ean Bitartean heldu eskutik poema-bilduman mota askotariko egunerokotasunean inspiratutako poesia eskaintzen du. Gai eta egoera ezberdinak jorratzen dira, gerrak eta aberriak esaterako. Adibidez, Bidaztia sorterriaz mintzo da sorterriaren gaineko poema: ${ }^{3}$

Gure desertuan ez da harearik./ Metalezko hesia zeharkatu eta / autopistan futbolean jolasten duten mutil koxkorrak badira. Gure itsasoan ez da urik./ Mila zaldi urdin ziren uhinak./Mila soldadurekin batera / eraman zituzten behin. Gure desertuan ez da harearik./ Baina bada harresi erraldoia, / ezin ikusi dugun arren, hurretik, / oso hurretik inguratu gaituena. Gure itsasoan ez da urik, /ez eta iraganaren uberarik. /Etorkizunak hondartzan dautza / malkoz eta ispilu hautsiez izorra. Gure desertuan ez da urik./ Gure itsasoan ez da harearik. (Uribe, 2001: online-ko bertsioa)

Aberriaren gaineko olerki honetan geroa hondartzan egonik harea eta ura ukitzen diren esparru malgua eta aldakorra baita. Aberria edo sorterria bizirik eta aldatzen den kolektibotasuna da, harresiak eta soldaduak alde batera utziz.

Lehen eleberria Bilbao-NewYork-Bilbao (2008) izan zen. Eleberri honetan idazlearen beraren familiaren hiru-lau belaunaldiak ardatz izanik euskal historia garaikidearen hainbat gai lantzen dira. Kortazar literatura teoriko eta kritikoak Uriberen literatura goraipatu du (2010). Kortazarren iritziz, Bilbao-NewYork-Bilbao eleberriak proposamen estetiko berri bat eskaintzen du, dimentsio ezberdinak txertatuz: auto-fikzioa, errealitatearen eta fikzioaren arteko mugak, literatura komunikaziorako era berriak eta familiaren historia. Kortazarren analisian, euskal jendeen historia garaikidean itsasoa lagun izan duen familia baten historia ez da galdu errealitatearekiko nostalgian. Geroan usadioetatik eratorritako euskal familia batentzat lekua dagoela uler daiteke, non bere tradizio kultural eta sozialekin globalizazioak ekarritako uhinetan barrena nabigatzea posible den. 2009an liburuak Espainiako Narratiba Saria lortu zuen (euskarazko literaturaren hirugarrena, bigarrena Elorriagak 2002an SPrako tranbia lanarekin lortu baitzuen; euskarazko literaturarako kopuru estimagarria, katalanez sari bakar bat izan dela kontuan izanda).

Uriberen lehen eleberriak hemen analizatzen diren bi gaiak ukitzen ditu. Batetik, herrihiri arteko zubigintza era natural batean integratzen du. Ondarroa bezalako itsas-herri bat eta nobelan agertzen diren hainbat hiri (Bilbao, New York, etab.) osagarri suertatzen dira. Ohiturak eta berrikuntzak mundu bakar bateko parte izan dira eta dira. Bestetik, aniztasuna adierazten duten gertaera eta egoerak daude. Kortazar (2010) eta Kortazar (2013) analistek azpimarratzen dutenez, euskal historia garaikideko aniztasun kulturala eta politikoa ezberdinen arteko erlazioen bidez adierazten da, batik-bat adiskide edo auzokide bezalako harremanetan. Esaldi pare batek laburbiltzen du aniztasunaren praxia. Bata, nobelako protagonista baten ahotan jarria: «Ideiak gauza bat dira, baina bihotza

\footnotetext{
${ }^{3}$ Hasieran, Sophia de Melloren bertsoak ditu: Betiko aberri galduaren / oroimen urruna. Ez dakigu / noiz galdu genuen: atzo ala bihar.
} 
beste gauza bat da»; honek gerra zibilaren eta diktaduraren garai latzetan eta krudeletan ideologia ezberdinez gain pertsonen arteko gutxieneko hartu-emanik egon daitekeela adieraziz. Bestea bikoitza da: «Ideologia ezberdinak zeuzkaten baina denek zioten elkarri begirunea» idazlearen ideia, eta idazlearen aitonaren itsasontziaren izena "dos amigos» (bi adiskide). Esapide hauek Bilbon XX. mendeko lehen hamarraldietan Bastida arkitekto kontserbadorea eta monarkikoak, Arteta margolari eta euskal nazionalistak eta Prieto politikari espainiar eta sozialistak garatu zuten adiskidetasuna adierazten dute, gerra zibilak eta heriotzak harremanak hautsi zituzten arte.

Eleberriak interpretazio kritikoagoa ere izan du. Atutxaren ustez (Atutxa, 2011; 2013), istorioak, formaz eta edukiz, efektu anbibalentea du euskal nazio edo herriaren irudi hegemonikoaren gainean; eleberriak euskal nazio/herriaren halako alegoria bat birlantzen du globalizazio neoliberalaren garaian, eta euskal jendea nolabait subalterno eta otzan agertzen da; eta horrela Espainiako estatuaren botere-estrategientzat nolabait lagungarri suertatuz. Gaztelerazko itzulpenean egin diren aldaketa batzuek analisi kritiko honi laguntzen diote. Hala ere, Atutxaren analisiak ez du obraren balioa ahultzen, ezta euskal errealitate anitza eta konplexua ulertzen laguntzeko lanak eskaintzen dituen ispiluak eta tresnak ere.

Elkarrekin esnatzeko ordua (2016) eleberri historikoan Uribek euskal familia nazionalista bateko emakume baten nondik-norakoak kontatzen ditu, gerra zibiletik ETAren sorrera eta demokraziarako trantsizioaren lehen urteak arte (1979). Benetako gertaera eta datuetan oinarriturik, euskal nazionalismo militantearen patua sinbolizatzen duen familia baten belaunaldien ibilbide gorabeheratsua da. Narrazioan maila eta izaera arras ezberdinetako istorioak daude, konplexitatearen adierazgarri: bi maitaleen arteko hurbiltze fisiko eta musukatzea, eta Franko eta AEBetako gobernuaren arteko elkarlana; Ondarroa bezalako itsas-herri bateko ohiturak, eta Frankoren komisaldegietako torturak; guraso eta seme-alaben arteko eta neba-arreben arteko harremanak; Pariseko kaleetako bizitza eta Venezuelako oihan eta naturaren xarma. Egiazko familia baten historia nobelatuan idazleak kazetari edo ikertzailearen lana egiten du, Mussche (2012) aurreko eleberrian egin zuen antzera. Gai etikoz eta galdera moralez osatutako historia da. Gerra zibil galdu bat eta ondorengo diktadura bat jasan eta honen aurka egiteak galdera horiek eragitea berezkoa du. Pertsonaia bihurtutako pertsonek, mundu konplexu, latz eta anitz batean murgildurik, galdera, duda, gogoeta eta dilema asko ibiltzen dituzte, gehi autoreak berak jarritakoak. Galdera handien gainean halako justizia-etika txiki bat garatzen duela dirudi, ezberdinen arteko aniztasunaren baldintzak eta praxiak adieraziz. 2016an eleberriak Akademia 111 saria jaso zuen.

Laburbilduz, Uriberen literaturgintzak euskal errealitateko gai garrantzitsuei heltzen die, herri-tradizio eta hiri-berrikuntza munduen arteko zubigintzari eta baita ezberdinen arteko aniztasunari ere. Era errealista batean egiten du. Istorio errealetan oinarritutako narrazioak maila, norabide eta garai ezberdinetan daude, eta horrek lana euskal errealitatearen konplexutasuna ulertzeko tresna izaten laguntzen du. 


\section{KONKLUSIOAK}

Artikulu honetan aurre-estudio bat aurkeztu da, hau da, datu enpirikoen gainean garatutako teorizazioaren lehen pausua. Soziologia pragmatikoan eta soziologia kultural konparatu berritu batean inspiratutako literaturaren soziologia bat bideratu da. Literaturak gaurko gizartean eduki dezakeen eragina aztertzeko, ispilu eta tresna metaforak kontzeptualizatu dira. Literaturak ispilu-tresna gisa izateko baldintza batzuk izan behar ditu: gutxieneko irakurlego eta estatusa izan, eta gizartearen ezaugarri garrantzikoak lantzea. Kontzeptu hauek ardatz eta gida izanik egungo euskarazko literaturari buruzko analisi soziologiko baten teorizazioaren lehen urratsa egin da.

Azken hamarraldietan euskarazko literaturak bilakaera dinamikoa eta bizia izan du. Oztopo eta mugapen estrukturalak gorabehera, eta internet-en garai nahasietan, euskarazko literaturak sistema literario baten lehen zutabeak eraiki ditu, eta gutxieneko irakurlegoa eta estatus instituzionala erdietsi ditu. Euskarazko literaturak euskal errealitatea izan ohi du erreferentzia. Euskal errealitatearen ezaugarri garrantzizko bi identifikatu dira: oinarrizko justizia eta berdintasun sozialen barruan herri-tradizioa eta hiri-berrikuntza munduen arteko zubigintza, eta ezberdinen arteko aniztasuna.

Beren literatura-lanetan bi ezaugarriok landu dituzten hiru idazle hautatu dira eta beren literatura-lanik esanguratsuenak aztertu dira: G. Aresti, B. Atxaga eta K. Uribe. Estatus maila altua duten hiru idazle hauek genero ezberdinak erabili dituzte, eta beren literatura-obrek ispilu edo tresna efektua eragiteko baldintzak dituzte. Nor bere garaiko kontestu eta baldintzapenetan, hautatutako bi gaiak era ezberdinetan jorratu dituzte. Diktadura frankistaren 1960 eta 1970ko hamarkada ilun eta zalantzagarrietan, G. Arestik euskal errealitatearen kontraesanak azaleratu zituen poesiaren bidez, bereziki hiritartutako jatorri eta izaera ezberdinetako euskal jende xehearen elkartasuna aldarrikatuz. Trantsizioko hamarraldi luzean, B. Atxagak hasiera batean poesian baina gero ipuingintzan euskal errealitateko herri-hiri arteko erlazio anbibalentea sinbolizatu zuen; Obabakoak-en ipuinen bidez, hedatzen ari zen mundu modernoarekiko euskal herri-tradizioetako mundua nola desagertzen, aldatzen eta txertatzen zen kontatzen da. Globalizazioaren garai bizienetan, K. Uriberen nobelagintza errealismo argi batean dago oinarritua; BilbaoNew York-Bilbao eta Elkarrekin esnatzeko ordua eleberrietan benetako familia batzuen bilakaeran oinarrituta euskal historia garaikidearen hainbat aldaketa, gai eta galdera landu ditu, eta bietan, bai sakonean, bai pasarte eta istorio zehatz askotan, tradizioa eta berrikuntzaren arteko zubigintzan eta ezberdinen arteko aniztasuna erakusten da.

Soziologiaren ikuspegitik, giza kolektibo garaikide baten erronketako bat bere izaera sozial konplexua eta anitza ulertu eta aitortzea dela esan liteke. Literaturak erronka eta helburu horretan lagun dezakeela argudiatu da. Literatura-egileek gizarte errealitate konplexua eta anitza lantzen duten narrazioak eta poesiak idatzi eta gizarteari eskaini ahala, gizarteak hauek tresna gisa hartuz bere izatearen gaineko auto-ulermen garatuagoa eraiki dezake. Izan ere, literatura, gizarte garaikide garatu baten kultura, ezagutza eta interpre- 
tatze-sistemako elementu garrantzizkoa da. Aurre-estudio honetan, literaturaren ispilutresna gisako eraginaren prozesu osoa ez da analizatu; horretarako denbora ikuspegi luzeagoa eta metodologia konplexuagoa behar dira. Gerora begira ikertze-lanetan erabiltzeko proposamena da.

\section{ERREFERENTZIA BIBLIOGRAFIKOAK}

Albrecht, M. C. (1954). The relationship of literature and society, American Journal of Sociology, vol. 59, n. ${ }^{\circ}$ 5, pp. 425-436.

Aldekoa, I. (1993). Antología de la poesía vasa / Euskal Poesiaren Antología. Madrid: Colección Visor de Poesia.

Aldekoa, I. (2008). Euskal Literaturaren historia. Donostia: Poltsiko Erein (2002: gaztelerazko jatorrizko bertsioa).

Alonso, I. (2012). Idazleen hierarkizazioa euskal sisteman: idazleen ikuspegia, eta irakaskuntzaren mikrosistema, UZTARO n. ${ }^{\circ}$ 81, pp. 41-59.

Aresti, G. (1984). Maldan behera / Harri eta herri. (Javier Atienzaren edizioa). Madrid: Cátedra Letras Hispánicas.

Aresti, G. (1986). Gabriel Aresti. Artikuluak, Hitzaldiak eta gutunak. Gabriel Arestiren Lanak-10. Bilboko Udala eta Bizkaiko Aldundia \& Susa.

Aresti, G. (1995). Euskal Harria (edizio elebiduna). Donostia: Orain.

Apalategi, U. (2009). Hiritiko ihesa: B. Atxaga eta M. Houllebecq-en ibilbide erkatuak. In Juan Mari Lekuonari omenaldia (pp. 65-78). Euskaltzaindia.

Atutxa, I. (2011). Kanonaren Gaineko Nazioaz: Euskal Identitatearen errepresentazioei buruzko azterketa Ziutateaz eta Bilbao-New York-Bilbaon. Donostia: Utriusque Vasconiae.

Atutxa, I. (2013). On the basque literary canon: Bilbao-New York-Bilbao and the construction of the Spanish nation state. Prosopopeya. Revista de critica contemporánea, n. ${ }^{\circ}$, pp. 193-212.

Atxaga, B. (1976). Ziutateaz,. Donostia: Haranburu-Altuna.

Atxaga, B. (1978). Etiopia. Bilbao, Pott Banda / (1983) Donostia: Erein. 
Atxaga, B. (1988). Obakakoak. Donostia: Erein.

Barnes, B. (1995). The elements of social theory. London: UCL.

Beljean, S., Chong, P. eta Lamont, M. (2016). A post-Bourdieusian sociology of valuation and evaluation for the field of cultural production. In Hanquinet, L. eta Savage, M. (eds.) Routledge international handbook of the sociology of art and culture (pp. 3848). London: Routledge.

Bourdieu, P. (1992). Les règles de l'art. Genèse et structure du champ littéraire. Paris: Éditions du Seuil.

Coser, L. A., eta Coser, L. A. (eds.) (1963). Sociology through literature: an introductory reader. Englewood Cliffs, NJ: Prentice-Hall.

Del Olmo, K. (2016). Aproximación al concepto de nación en el teatro de Gabriel Aresti. In Kortazar, J. (ed.) (2016) Autonomía y ideología. Tensión en el campo cultural vasco (pp. 111-140). Madrid: Iberomericana.

Dromi, S. M., eta Illouz, E. (2010). Recovering morality: Pragmatic sociology and literary studies. New literary history, vol. 41, n. ${ }^{\circ}$ 2, pp. 351-369.

Egaña, I. (2015). Izan gabe denaz. Hogeita hamar urte euskal hedabideetako literatur kritikan. Donostia: Utriusque Vasconiae.

English, J. F. (2010). Everywhere and nowhere: the sociology of literature after «the sociology of literature. New Literary History, vol. 41, n. ${ }^{\circ}$, pp. xxiii. New Sociologies of literature.

Even-Zohar, I. (1993). Función da literatura na creación das nacións de Europa. Grial, n. ${ }^{\circ}$ XXXI, pp. 441-458.

Even-Zohar, I. (2005). Polysystem theory (revised). Papers in culture research, 38-49.

Ferguson, P. P., Desan, P., eta Griswold, W. (1988). Editor's Introduction: mirrors, frames, and demons. Reflections on the sociology of literature. Critical Inquiry vol. 14, n. $^{\circ} 3$, (The sociology of literature), pp. 421-430.

Gabilondo, J. (1993). Etiopiaz kanonaren sorrera egungo euskal literaturan. Egan 2, p. 3365.

Gabilondo, J. (2016). Before Babel: A History of Basque Literatures (http://www.barbaroak. com). 
Griswold, W. (1987). The Fabrication of Meaning: Literary Interpretation in the United States, Great Britain, and the West Indies. American Journal of Sociology, vol. 92, n. ${ }^{0}$ 5, pp. 1077-1117.

Griswold, W. (1993). Recent moves in the Sociology of Literature. Annual Review of Sociology, n. ${ }^{\circ} 19$, pp. $455-467$.

Kortazar, J. (ed.) (2009). Egungo euskal poesiaren historia. Leioa: Euskal Herriko Unibertsitatea.

Kortazar, J. (2010). Bitartean New York, Kirmen Uriberen literaturgintza. Donostia: Utriusque Vasconiae.

Kortazar, J. (2016). La poesía de Gabriel Aresti, un proceso de ideologización en la literatura vasca contemporánea. In Kortazar, J. (ed.) (2016) Autonomía y ideología. Tensión en el campo cultural vasco (pp. 73-110). Madrid: Iberomericana.

Kortazar, J., eta Retolaza I. (eds.) (2007). Egungo euskal eleberrien historia. Leioa: Euskal Herriko Unibertsistatea.

Kortazar, P. (2013). La identidad en la narrativa vasca contemporanea: Harkaitz Cano y Kirmen Uribe. Insula: revista de letras y ciencias humanas, n. 797 (Ejemplar dedicado a literatura vasca: puertos abiertos) pp. 30-32.

Lamont M. eta Thévenot, L. (eds.) 2000 Rethinking Comparative Cultural Sociology: Polities and Repertoires of Evaluation in France and the United States. London: Cambridge University Press.

Lepenies, W (1988). Between Literature and Science: The Rise of Sociology. Cambridge: Cambridge University Press.

Lukács, G. (1966). Sociología de la literatura. Madrid: Ediciones Península.

Mercero, G. (2017). Mundu-ikuskerak euskal narratiba garaikidean: modernitatearen krisitik postidentitatearen promesera. Labayru Fundazioa/Amorebieta-Etxanoko Udala.

Olaziregi, M. J. (2009). Literaura vasca e identidad nacional. Revista de lenguas y literaturas catalana, gallega y vasca, n. ${ }^{\circ} 14$, pp. 355-369.

Parker, R. D. (2008). How to interpret literature: Critical theory for literary and cultural studies. Oxford: Oxford University Press.

Retolaza, I. (2007). Hamaika muga, hamaika irakurbide. In Kortazar, J. eta Retolaza I. (eds.) Egungo euskal eleberrien historia (pp. 13-64). Leioa: Euskal Herriko Unibertsitatea. 
Romero, H., eta Santoro, P. (2007). Dos caminos en la sociología de la literatura: hacia una definición programática de la sociología de la literatura española. Revista Española de Investigaciones Sociológicas n. ${ }^{\circ}$ 8, pp. 195-223.

Romero, L. (2008). Literatura y nación: la emergencia de las literaturas nacionales. Zaragoza: Prensas Universitarias de Zaragoza.

Rorty, R. (1989). Contingency, irony and solidarity. Cambidge: Cambridge University Press.

Sarasola, B. (2016). Bainaren belaunaldia. Bilbo: Labayru fundazioa.

Silber, I. F. (2003). Pragmatic sociology as cultural sociology: beyond repertoire theory?. European Journal of Social Theory, vol. 6, n. ${ }^{\circ}$ 4, pp. 427-449.

Subirats, E. (1993). Despues de la lluvia. Sobre la ambigua modernidad española. Madrid: Temas de Hoy.

Subirats, E. (ed.). (2002). Intransiciones: crítica de la cultura española. Madrid: Biblioteca Nueva.

Swedberg, R. (2012). Theorizing in sociology and social science: Turning to the context of discovery. Theory and society, vol. 41, n. ${ }^{0}$ 1, pp. 1-40.

Swidler, A. (1986). Culture in action: Symbols and strategies. American sociological review, vol. 51, n. ${ }^{\circ}$, pp. 273-286.

Uribe, K. (2001). Bitartean heldu eskutik. Zarautz, Iruñea, Larrabetzu: Susa (online-ko bertsio elektronikoa: www.susa-literatura.eus).

Uribe, K. (2008). Bilbao-New York-Bilbao. Donostia: Elkar.

Uribe, K. (2016). Elkarrekin esnatzeko ordua. Zarautz, Iruñea, Larrabetzu: Susa.

Vilarós, T. M. (1998). El mono del desencanto: una crítica cultural de la transición española, 1973-1993. Madrid: Siglo XXI.

Weber, D. (2000). Culture or commerce? Symbolic boundaries in French and American book publishing. In Lamont M. eta Thévenot, L. (eds.) 2000 Rethinking Comparative Cultural Sociology: Polities and Repertoires of Evaluation in France and the United States. (pp. 127-147). London: Cambridge University Press.

Zaldua, I. (2016). (Euskal) literaturaren alde (eta kontra). Donostia: Elkar. 